\title{
THE IMPACT OF COVID-19 ON SOUVENIR INDUSTRY IN MARINE TOURISM AREAS IN INDONESIA
}

\author{
Indah Pambudi Arumsari ${ }^{1}$, Rolisda Yosintha ${ }^{2}$ \\ ${ }^{1,2}$ Faculty of Teacher Training and Education \\ Tidar University \\ Jl. Kapten Suparman No.39, Tuguran, Potrobangsan, Kec. Magelang Utara, Kota \\ Magelang, Jawa Tengah 56116 \\ indahpambudiarumsari@gmail.com
}

Accepted: 15 Juni 2020. Approved: 24 Mei 2021. Published: 28 Juni 2021

\begin{abstract}
Covid-19 is a lethal virus that is being faced by the world. Many sectors are affected by the virus, including the marine tourism industry and all people who work in this industry. This study aimed to investigate the impact of Covid-19 on souvenir traders in the marine tourism area in Indonesia. The researchers used a qualitative method to collect the data and descriptive analysis to analyze the data. The findings show that Covid-19 has detrimentally affected souvenir traders in marine tourism areas in Indonesia as they lost nearly 100\% of their income from tourist visits. To overcome this income deficit, most of them choose to switch professions to become farmers, fishermen, seaweed farmers, and antiseptic gel makers.
\end{abstract}

Keywords: covid-19, marine tourism, souvenir industry

C) 2021 Direktorat Kajian Strategis

\section{INTRODUCTION}

The world is now suffering from the spread of coronavirus disease 2019 (Covid-19). This disease is a type of infectious disease that was not widely known before the outbreak that struck Wuhan, China, in December 2019. Covid-19 can easily spread when a person who is not infected with Covid-19 accidentally inhales or holds an object that has been contaminated with a spark that comes from a positive person with Covid-19. The hand that has touched the object affected by the spark when it touches the eyes, nose, or mouth will be the way of the virus entering a person's body. WHO also says that the common symptoms of Covid-19 are such as fever, dry cough, and fatigue. Other symptoms felt are headache, shortness of breath, sore throat, diarrhea, loss of sense of smell or taste, conjunctivitis. Usually, these symptoms come gradually and vary depending on the severity that occurs. People who are elderly and have comorbidities will experience more severe pain.

In Indonesia, the number of positive corona cases continues to 
increase. This condition makes the Indonesian government continue to enact policies related to this pandemic. It begins with an appeal to stay at home for only 2 weeks last March, but until now Indonesian people are still being asked to stay at home. According to an official report in https://covid19.go.id/, the number of positive corona cases in Indonesia reached 23,165 on May 26, 2020. As many as 5,877 patients recover from this disease reach, while 1.418 patients die. The people who were initially encouraged to stay at home for only 2 weeks now have to be patient again because the policy continues to be extended. Starting March 2020, the government ordered many institutions, including those in the education sectors, to Study from Home or Work from Home to prevent the spread of this virus. In addition, many public places that are usually busy and crowded such as shopping malls, tourist attractions, and places of worship are also on temporary closure.

Furthermore, on the official website of the Covid-19 countermeasure in Indonesia concerning the PSBB (Large-Scale Social Restrictions) which makes the school be shut down, Anis Baswedan will extend the policy to 4 June 2020. In Jakarta itself, per the DKI Jakarta Governor Regulation (Pergub) Number 47 the Year 2020 regarding Exit Permit (SIKM), which regulates the obligations that must be fulfilled by citizens who will enter the DKI Jakarta Province. The letter said that those who were permitted were health, finance, logistics, strategic industries, food, energy, hospitality, construction, communication, and information technology, the fulfillment of daily needs, basic services, public utilities, and industries determined as objects national vital and certain objects. Other requirements such as health certificates, Swab Polymerase Chain Reaction (PCR) tests, official letters from agencies or companies, and other travel documents such as official identity cards. Even this regulation is also applied in Indonesia. From those things, it means that people cannot leave or enter Indonesia as freely as before.

The travel ban, which leads to access restrictions, brings about further impacts on the tourism industry in Indonesia as this regulation directly diminishes the number of travelers, either domestic or foreign. To prevent the spread of Covid-19, several tourism departments have instructed to temporarily close almost all tourism destinations in their regions, including marine tourism attractions. Based on (Asnida Riani, 2020), Lovina and Pandawa beaches in Bali have been closed since March. Not only that (Imam Rosidin, Robertus Belamirnus, 2020) also said that Kuta beach and all attractions in Badung, Bali were also closed. Other tourist objects such as Sayang Heulang beach in West Java were also closed (Fitri Nursaniyah, 2020), and several beaches in Gunung Kidul were also closed by the Gunung Kidul Regency Government (antaranews.com, 2020).

Indonesia is the largest archipelagic country in the world with 17,499 islands across the equator. With $81,000 \mathrm{~km}$ of coastline, tourists can find countless marine tourism spots in Indonesia (West Java Government, 2017). To Indonesia, these marine tourist attractions are very important to support. Quoted from Suara.com, maritime tourism in Indonesia donated 1 billion US dollars in 2019. (Akhdi Martin Pratama, Erlangga Djumena, 2019) released that at the end of 2019 the tourism sector could reap foreign exchange totaling 17.6 billion (Rp246.4 trillion) through the program 10 Bali Baru, 7 of the 10 destinations are marine tourism including Tanjung Kelayang (Belitung), Tanjung Lesung (Banten), Mandalika (West Nusa Tenggara), Labuan Bajo (East Nusa 
Tenggara), Wakatobi (Southeast Sulawesi), and Morotai (Maluku North). This shows that marine tourism in Indonesia also affects the country's foreign exchange. However, because of the Covid-19 pandemic, some regions that rely on the marine industry suffered significant losses due to the absence of tourist visits. Quoted from the website (Widodo, 2020), the Chairman of the Indonesian Tourism Industry Association in Bali, Ida Bagus Agung Partha Adnyana, said that the decline in Bali tourism reached $93 \%$ compared to the same period last year Tourism destinations in Bali which is very bad is a type of marine tourism, he concluded. The dive tourism businesses in Labuan Bajo, West Manggarai, East Nusa Tenggara, are also forced to close their businesses due to the effects of this coronavirus. Marcia Stephanie, a dive operator in Labuan Bajo who closed the door of her business for a while said that the losses in her company reached hundreds of millions (Bali.bisnis.com, 2020).

In marine tourism, of course, many parties play a role in supporting this industry. It is not only the visitors, hotel or inn providers, and fishermen who play a significant role in this industry, but also souvenir merchants. When visiting marine tourism spots, visitors are often besieged by souvenir merchants who sell beautiful souvenirs, such as key chains, beach nuanced photo frames, tissue boxes, necklaces, bracelets, seashells curtain, decorative lamps, beautiful decorative hangers, and many other products. These things are of course made from the natural resources in the see such as conch shells, starfish, sea slug shells, and many more. Some people who live on the coast do not only work as fishermen or fishmongers but also produce beachfront souvenirs for sale. This work is considered safer than a fisherman who has to fight against the swift waves in the sea. From teenagers to older people, they can produce souvenirs with a variety of very beautiful models.

Not only for local trade, but beach souvenirs are also beginning to be in demand by traders in big cities. Even recently, the market demand for beach souvenirs has also expanded because it has been exported to neighboring countries such as Thailand, Singapore, Malay, China, and so on. The Marketing Manager of Multi Dimensi ShellCrafts, a company running in the souvenir industry, said that-around 2010 to 2015, the total number of exported goods reaches 100 to 150 thousand USD each month (Astutik, 2019).

The increase in the number of orders also affected the number of employees employed, with the highest number reaching 500 people. They can sell the products to China, Thailand, Hongkong, and other countries. With such a huge amount of income generated from the souvenir industry and employability increase, the souvenir industry has contributed to the addition of foreign exchange (CNBC INDONESIA, 2019). Considering the important role played by the souvenir industry in marine tourism areas, it is very important to investigate the effects of Covid-19 on the souvenir industry in marine tourism in Indonesia.

Talking about souvenirs, we need to know that souvenir sales are quite important. For residents around the coast, they will make this business a livelihood. Not only that, but souvenirs are also a medium to introduce tourism spots by showing their characteristics through these souvenirs. Many tourists are looking for and then buying souvenirs to save the memories even a gift for those closest to them who cannot vacation together. Another thing also shows that souvenir sales are a supporting business in the tourism sector. As said by Andinata (2010), the other production sectors in tourism include the handicraft industry, souvenirs, accommodation, and 
transportation. Asmara (2020) also said that there are several tourism supports, namely the availability of travel agencies, accommodation, transportation, catering services and restaurants, money charges / money changers, tourist attractions, and souvenirs such as souvenirs.

Based on the things that have been mentioned above, it can be said that souvenirs are part of the support which has many benefits. However, in the current pandemic era, souvenir industry activities appear to be affected by Covid19. Based on the results of a survey conducted by the Ministry of Tourism and Creative Economy, $0.97 \%$ of other types of businesses affected by Covid 19 include souvenir shops, spa houses, and other tourism services (Suprihatin, 2020). Other research was conducted by Hadiwardoyo (2020), in his research on National Economic Losses Due to the Covid-19 Pandemic, that the sectors that were hardest hit were places that rely on crowds, one of which is tourism, and supporting businesses such as mass transportation, ticketing, hotels, and souvenirs.

In this current pandemic era many sectors are affected, one of which is the tourism sector. According to UNWTO (2020), it is estimated that 850 million to 1.1 billion international tourists have decreased. This causes components in tourism to also experience a decrease in income, one of which is in the field of souvenir sales. This is due to the decreasing level of tourist visitors, especially marine tourism, which makes souvenir traders lose many buyers. We can observe that covid-19 is increasing, while the rate of souvenir sales is decreasing. It can be the general implication of Covid-19 on souvenir traders. the decline in souvenir sales poses a risk to the economy of souvenir traders who depend their financial fortunes on tourists who buy these souvenirs.

\section{METHOD}

This study aims to know the impact of Covid-19 on the souvenir industry in marine tourism areas. The researchers used a qualitative method to collect the data by founding data through journals, articles, websites, and ministry letters. Therefore, those resources were chosen because $t$ hey presented statements and facts about the conditions of souvenir traders in marine tourism areas. The data were then analyzed using a descriptive qualitative technique. The descriptive analysis aimed at collecting data with good actuality which illustrated the real conditions. This whole process did not only aim to identify the problems but also to investigate the solutions to make the conditions better based on the data and the experience.

\section{RESULTS AND DISCUSSION}

The component in the tourism sector is certainly not only about the location and natural beauty that is presented. Among them, there are also other components such as facilities and the art market or place of selling souvenirs typical of the tourist attractions that will add to the attractiveness of the spots. Every tourist spot has its characteristics as well as souvenirs for sale.

Souvenirs sold in marine tourism include a variety of craft shells transformed into room decorations, mirror decoration, miniature animals, and brooches. No less unique is the presence of souvenir merchants who sell notched rings and Jenitri bracelets and necklaces (Retno, 2016). The price range is set starting from IDR 4,500 - 65,000 (Indonesian tourism, 2020) (Souvenir Shells, 2020). At the end of the holidays in 2019, visitors to Parangtritis Beach were around 30 thousand tourists (IDN Times, 2020), but in March the Bantul Regency Government closed all tourist 
attractions including Parangtritis Beach. This makes the income of traders in Parangtritis Beach shows IDR 0 (Pertana, 2020).

Not only in Parangtritis Beach, traders in Kuta Beach, Bali, also complained about the lack of tourists there. One souvenir merchant who was there said that in a day usually gets a profit of Rp. 600,000 - Rp. 400,000 in a day in November or December 2019 ago, but with the existence of this pandemic, tourist visits in the art market declined dramatically (Merdeka.com, 2020).

The absence of visitors was also felt by ArtShop traders in Sanur Beach, Bali. There are only a few local tourists and 2 foreign tourists who still survive in Bali. Usually, Sanur Beach Bali is never empty of visitors and is always crowded (NusaBali.com, 2020). However, due to the impact of Covid-19, tourists choose to stay at home. This makes the income of souvenir traders who are around Sanur Beach, Bali, suffered a substantial loss due to the lack of income from the sale of souvenirs.

To improve this condition, some souvenir sellers choose to sell their personal belongings to survive, as said by one of the souvenir traders in Parangtritis Beach (Pertana, 2020). Not only that, but government assistance also came to help the economy and lighten the burden of traders around the Kebumen beach such as Logending Beach, Karangbolong Beach, Suwuk Beach, Petanahan Beach, and Leguna Lembupurwo Beach by providing food packages (Heksantoro, 2020). One of the residents in Nusa Penida, Bali, also said that many had switched professions because of the covid-19 to become farmers, fishermen, and seaweed farmers (BALIPOST.com, 2020). Rumah Rumpu Laut (RRL) even produces antiseptic gel at an affordable price so that it can increase sales turnover (kumparan.com, 2020).

In other tourist attractions, namely animal husbandry attractions, souvenirs for sale also have different variations. Souvenirs are sold at the zoo in the form of animal t-shirts, key chains, sandals, dolls, mugs, and stickers. Prices set by souvenir sellers at the zoo tour are around IDR $10,000-68,000$. The data is based on the recognition of one of the officers at the Harsum Souvenir Kiosk in Ragunan Wildlife Park, Jakarta (TRIBUNNEWS.COM, 2012). With the existence of this pandemic, in March 2020 the DKI Jakarta Provincial Government even had to close Ragunan Wildlife Park, Jakarta (Grandyos Zafna, 2020). This causes no tourist visits to simply see the animals that exist, especially to buy souvenirs that are sold there.

In religious tourism, souvenirs that are sold are also diverse such as prayer beads, gloves, kopyah, shirts, and key chains, calligraphy, paintings, or posters about religious figures (JawaPost.com, 2018). The price range in the souvenir is IDR 5,000 - 90,000. One example of religious tourism that is visited every day is the Gusdur Grave Tourist Area. Besides being able to make a pilgrimage at Gus Dur's grave, tourists can also shop for souvenirs. One of the visitors said that the selling price of souvenirs there is cheap and has a large selection of items (FACTUALNEWS.CO, 2018). However, due to the pandemic that is being experienced by the Indonesian state, based on the Circular Letter (SE) of Tebuireng Ponpes number 1524 / I / HM 0001 / PENG / 2020 dated March 14, 2020, the tomb of Gus Dur must be temporarily closed until an indefinite time. This has led to the absence of tourists and also the purchase of souvenirs (detikcom, 2020).

In addition, historical tourism in Indonesia is also quite a lot considering the many tragedies that befell the Indonesian state before and after them. One example of historical tourism in Indonesia which is quite famous is the historical tourism monument. In the 
historical tour of Monas, souvenirs are sold in the form of typical Monas trinkets such as miniature monas key chains, $t$ shirts that are on sale at low prices $(\mathrm{CNN}$ Indonesia, 2020). At the close of 2019 , Monas was very hemp visited by both local and foreign tourists. The tourists still enjoy the atmosphere by sitting casually down to the parks in Monas. But some tourists are less able to feel the atmosphere of Monas because it is too crowded. This also had a good impact on souvenir sales because at the close of 2019 there were very many visitors (KOMPAS.com, 2019). However, last March, the Governor of DKI Jakarta closed a number of tours managed by the Provincial Government of DKI Jakarta including Monas (detikcom, 2020). This closure makes several tourists has decreased dramatically; souvenir sales are also reduced by $100 \%$.

Overall, almost all tourist attractions in Indonesia suffer from Covid-19 by the dramatic decline in tourist arrivals. This condition has led to a severe blow on souvenir sellers in those spots as summarized in Figure 1.

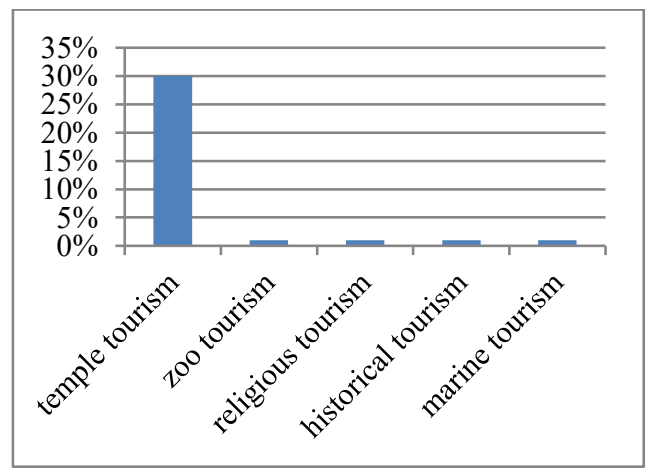

Figure 1. Souvenir purchase in some tourist attractions in Indonesia

As shown in Figure 1, there is a decrease in the sales of souvenirs in the Indonesian tourism sector. The graph answers researchers' questions about the impact of Covid-19 on souvenir traders in marine tourism areas. The graph shows that souvenir merchant income or souvenir purchase level is highly affected. In the marine tourism sector, souvenir purchases indicate $0 \%$ interest, which means there are no purchases that occur due to the closing of marine tourism.

But it is not only marine tourism that is affected, temple tourism is also affected and only shows $30 \%$ in terms of souvenir purchases. Other tours such as wildlife tourism, religious tourism, historical tourism also show $0 \%$. It can be seen in the graph the most souvenir sales are in temple tours. This finding proves that the presence of this coronavirus affects the sales of existing souvenirs. The closure of the tour makes tourists zero and empty souvenir buyers. The data that has been collected also illustrates that the most affected are marine tourism because in the data above it is stated that at the close of 2019 visitors to Parangtritis Beach (which is included as one of marine tourism) shows figures up to 30 thousand tourists. Whereas with the existence of this pandemic, souvenir merchants said that there no tourists were visiting and buying souvenirs.

With the results and discussion above, we can analyze that Covid-19 affects souvenir sales, especially in the marine tourism sector. The finances of souvenir traders on marine tourism are under threat due to the decline in the number of tourists because of the coronavirus. Not only that, the seekers of materials for making souvenirs around the beach also felt the impact. Those things are including the profound impact of Covid-19 on sales and workers involved in the souvenir business.

Quote from (KOMPAS.TV, 2020) the existence of this coronavirus outbreak has made several souvenir shops in Sorong experience a decrease in turnover of up to $80 \%$ compared to before the coronavirus. This is due to the absence of tourists who come to marine tourism in Raja Ampat Regency, Papua Province. On the other hand, it is written that if the 
tourism industry has decreased, it will affect other industries such as hotels, transportation, restaurants, and souvenirs (Fajar, 2020).

The researchers found not only a profound impact but also the effect of the decline in souvenir sales in economic and social aspects. From the economic-point of view, Covid-19 makes some souvenir traders decrease such as the financial. The researcher can analyze that based on the data that have been written above. Moreover, it also happens in social impact. Many corporations have to decide on lay off the workers due to those pandemics. This is done by the souvenir company because there are no consumers or buyers. It is making the company does not have money to pay its workers. Besides, there are changes in the sales system. Initially, souvenir sellers were selling by opening shops or directly marketing them. However, now souvenir sellers have to replace the sales system with the online market.

With the research and accurate news from other sources mentioned above, researchers found a similarity. The coronavirus does have a bad impact on the world of tourism, one of them is an effect on the tourism support sector, such as the souvenirs industry.

\section{CONCLUSIONS AND SUGGESTIONS}

The research concludes that Covid-19 does affect the tourism sector, especially in the sale of souvenirs. Souvenir merchants in the marine tourism area are very affected, with $0 \%$ data purchase of souvenirs in the marine tourism area in Indonesia. This study also aims to determine the impact of Covid-19 on souvenir traders in the marine tourism area. With this research, it is expected that the government may immediately take action to improve the economy of souvenir merchants in the tourism area, including temple tourism, religious tourism, historical tourism, zoo tourism, and marine tourism in particular. Souvenir merchants themselves are also expected to have innovations for other jobs as a substitute for jobs other than selling souvenirs. One of the innovations that suitable for this current situation is that souvenir traders can take advantage of technology to market their merchandise online. It can be done so that souvenir traders can still sell and promote their merchandise in the current pandemic situation.

\section{BIBLIOGRAPGHY}

Akhdi Martin Pratama, Erlangga Djumena. (28. July 2019). Sektor Pariwisata Ditargetkan Raup Devisa Rp 246 Triliun di 2019. KOMPAS.COM: https://money.kompas.com/read/2019 /07/28/172200726/sektor-pariwisataditargetkan-raup-devisa-rp-246triliun-di-2019-

Antaranews.com. (24. March 2020). Pemkab Gunung Kidul tutup seluruh objek wisata pantai. Haettu 14. June 2020 osoitteesta

Andinata, S. (2010). Identifikasi Produk Khas Semarang Yang Potensial Dikembangkan Menjadi Souvenir Kota Semarang. Doctoral dissertation, Prodi Manajemen Unika Soegijapranata), 2.

Asnida Riani. (23. march 2020). Daftar Objek Wisata, Restoran, dan Beach Club di Bali yang Tutup Sementara Akibat Corona COVID-19. LIPUTAN6: https://m.liputan6.com/lifestyle/read/ 4209394/daftar-objek-wisatarestoran-dan-beach-club-di-bsliyang-tutp-sementara-akibat-coronacovid-19

Balipost.com. (9. March 2020). Wisman Seoi, Warga Nusa Penida Alih Profesi. BALIPOST.com: http://www.balipost.com/news/2020/ 03/09/10852

CNN Indonesia. (23. February 2020). Wisata Sejarah Modal 'Goceng' di Monas. CNN Indonesia: https://www.cnnindonesia.com/gayahidup/20200221215120-269- 
477001/wisata-sejarah-modalgoceng-di-monas

Detikcom. (14. March 2020). Cegah Penyebaran Corona, Begini Kondisi Monas yang Ditutup Anies. detikcom: https://news.detik.com/berita/d4938733/cegah-penyebaran-coronabegini-kondisi-monas-yang-ditutupanies

Detikcom. (15. march 2020). Cegah Potensi Penyebaran Corona, Wisata Religi Makam Gus Dur Ditutup. detikcom: https://news.detik.com/berita-jawatimur/d-4939864/cegah-potensipenyebaran-corona-wisata-religimakam-gus-dur-ditutup

Faktualnews.co. (18. MARCH 2018). Asyiknya Belanja di Pusat Oleh-oleh Kawasan Wisata Makam Gus Dur. FAKTUALNEWS.CO: https://faktualnews.co/2018/03/18/as yiknya-belanja-pusat-kawasanwisata-makam-gus-dur/71989/

Fitri Nursaniyah. (25. Mei 2020). Cegah Penyebaran Corona dari Wisatawan, Pantai Sayang Heulang Garut Ditutup Sementara. PRBandungrayacom: https://prbandungraya.pikiranrakyat.com/jawa-barat/pr26388679/cegah-penyebaran-coronadari-wisatawan-pantai-sayangheulang-garut-ditutup-sementara

Grandyos Zafna. (14. March 2020). Kebun Binatang Ragunan Ditutup Imbas Corona. detikcom: https://travel.detik.com/fototravel/d4938859/kebun-binatang-ragunanditutup-imbascorona/3/\#detail_photo

Hadiwardoyo, W. (2020). KERUGIAN EKONOMI NASIONAL AKIBAT PANDEMI COVID-19. Baskara, 8392.

Heksantoro. (23. April 2020). Pedagang di Objek Wisata Kebumen Dapat Sembako Selama Corona. detikTravel:

https://travel.detik.com/travelnews/d-4987767/pedagang-di-objekwisata-kebumen-dapat-sembakoselama-corona

IDN Times. (1. january 2020). 30 Ribu Wisatawan Padati Pantai Parangtritis Saat Libur Tahun Baru. IDN TIMES JOGJA: https://jogja.idntimes.com/travel/desti nation/daruwaskita/30-ribu-

wisatawan-padati-pantai-parangtritissaat-libur-tahun-baru/1

Imam Rosidin, Robertus Belamirnus. (1. April 2020). Cegah Covid-19 Meluas, Pantai Kuta dan Seluruh Obyek Wisata di Badung Ditutup. KOMPAS.COM:

https://regional.kompas.com/read/202 0/04/01/11170391/cegah-covid-19meluas-pantai-kuta-dan-seluruhobyek-wisata-di-badung-ditutup

JawaPost.com. (24. Desember 2018). Wisata Religi Makam Gus Dur; Tersedia Banyak Merchandise. JawaPost.com: https://radarjombang.jawapos.com/re ad/2018/12/24/110059/wisata-religimakam-gus-dur-tersedia-banyakmerchandise

Jo souvenir. (14. october 2018). Informasi 5 Daftar Souvenir Unik dari Candi Prambanan. josouvenir.com: https://josouvenir.com/informasi/daft ar-souvenir-candi-prambanan

Kompas.tv. (2020, April 21). Dampak Covid19 Toko Oleh-oleh Sepi Pengunjung. Retrieved from KOMPAS.TV: https://www.kompas.tv/article/77167/ dampak-covid-19-toko-oleh-olehsepi-pengunjung

Kompas.com. (29. december 2019). Kawasan Monas Ramai Pengunjung saat Libur. KOMPAS.com:

https://foto.kompas.com/photo/read/2 019/12/29/15776261695cc/1/Kawasa n-Monas-Ramai-Pengunjung-saatLibur

Kumparan.com. (1. Mei 2020). Tenant Incubie IPB Tetap Berproduksi di Masa Pandemi COVID-19 Sambil Berbagi. kumparan.com: https://kumparan.com/news-release$\mathrm{ipb} /$ tenant-incubie-ipb-tetapberproduksi-di-masa-pandemi-covid19-sambil-berbagi1tKSVUq5dL3/full

Merdeka.com. (13. March 2020). Para Pedagang Keluhkan Sepinya Turis di Kuta Bali. Merdeka.com: https://www.merdeka.com/peristiwa/ para-pedagang-keluhkan-sepinyaturis-di-kuta-bali.html

NusaBali.com. (3. April 2020). Dampak Covid-19, Kawasan Wisata Pantai 
Sanur Sepi. NusaBali.com: https://www.nusabali.com/berita/713 29/dampak-covid-19-kawasanwisata-pantai-sanur-sepi

Pertana. (12. April 2020). Dampak COVID19, Pedagang di Parangtritis Nol Pendapatan. detikTravel: https://travel.detik.com/travelnews/d-4974306/dampak-covid-19pedagang-di-parangtritis-nolpendapatan $/ 2$

Pradito Rida Pertana. (12. April 2020). Dampak COVID-19, Pedagang di Parangtritis Nol Pendapatan. detikcom:

https://travel.detik.com/travelnews/d-4974306/dampak-covid-19pedagang-di-parangtritis-nolpendapatan

ProdakwisataIndonesia. (januari 2020). Gantungan Kunci Kerang wisata bahari. tokopedia: https://www.tokopedia.com/prodakwi sata/gantungan-kunci-kerang-wisatabahari

Retno. (18. april 2016). Oleh-Oleh Khas Dari Pantai Parangtritis. http://yogyakarta.panduanwisata.id/d aerah-istimewayogyakarta/bantul/oleh-oleh-khasdari-pantai-parangtritis/

Suprihatin, W. (2020). Analisis Perilaku Konsumen Wisatawan Era Pandemi Covid-19 (Studi Kasus Pariwiwsata di Nusa Tenggara Barat). Jurnal Bestari, 57.

Souvenir Kerang. (january 2020). kap lampu kor kor kerang laut asl. tokopedia.com:

https://www.tokopedia.com/ekalewis kykerang/kap-lampu-kor-kor-keranglaut-asli

Souvenir, j. (14. october 2018). Informasi 5 Daftar Souvenir Unik dari Candi Prambanan . josouvenir.com: https://josouvenir.com/informasi/daft ar-souvenir-candi-prambanan

Tokopedia. (2020). Souvenir Candi Prambanan. Tokopedia: https://www.tokopedia.com/souvenir candi

Tribunjogja.com. (13. march 2020). Dampak Corona Wisatawan Merosot, Pengelola Candi Prambanan dan Borobudur Siapkan Strategi
Lain.TribunJogja.com:

https://jogja.tribunnews.com/2020/03

/13/dampak-corona-wisatawanmerosot-pengelola-candi-prambanandan-borobudur-siapkan-strategi-lain

Tribunnews.com. (20. AUGUST 2012). Kios Cinderamata TM Ragunan Panen Rezeki. TRIBUNNEWS.COM: https://www.tribunnews.com/ramada n/2012/08/20/kios-cinderamata-tmragunan-panen-rezeki

Wahyu Setyo Widodo. (24. April 2020). Wisata Bali Turun 93\%! Ini yang Paling Parah Kena Dampak. detikcom:

https://ravel.detik.com/travelnews/d-4990005/wisata-bali-turun93-ini-yang-paling-parah-kenadampak

West Java Government. (3. November 2017). Official Website of. Noudettu osoitteesta

https://jabarprov.go.id/En/index.php/ news/4597/2017/11/03/Indonesia-isMaritime-Country-with-the-WorldsLargest-Islands

Yuni Astutik. (20. december 2019). Kilau Kerajinan Kerang Cirebon yang Tembus Pasar AS \& Italia. https://www.cnbcindonesia.com/entre preneur/20191220204850-25124886/kilau-kerajinan-kerangcirebon-yang-tembus-pasar-as-italia 